\title{
Bone Marrow Disease Involvement Indicator
}

National Cancer Institute

\section{Source}

National Cancer Institute. Bone Marrow Disease Involvement Indicator. NCI Thesaurus.

Code C135477.

An indication as to whether disease is present in the bone marrow. 